\title{
THE IMPACT OF FISCAL AND MONETARY POLICY ON THE HOUSING MARKET* .
}

\author{
Thomas H. Naylor $\dagger$
}

I

\section{Structure of the Housing Market}

When one speaks of the "housing market" he is in reality referring to four interrelated submarkets: (I) newly constructed single-family houses not yet sold or occupied, (2) new rental units, (3) previously occupied units being offered for resale, and (4) previously occupied units offered for rent. ${ }^{1}$ In this article we shall focus our attention on new housing, submarkets ( $\mathrm{x}$ ) and (2), but we shall by no means ignore the influence of previously occupied resale and rental units on purchases of new housing.

Since World War II expenditures for the purchase of new housing have been estimated to be about four per cent of Gross National Product (GNP). If one includes expenditures for equipment, furnishings, services, and so on which accompany the purchase of new housing, then the broader class of expenditures for new housing approaches twelve per cent of the GNP.?

Three different groups of individuals make decisions to construct new houses: (I) individuals who contract for or build a house for their own use, (2) builders who start houses that they expect to sell to new owner-occupiers, and (3) builders who start rental units. Although the percentages of new housing starts in these three groups vary widely from month to month, in the early 1960 s the market was roughly divided one-quarter, one-half, and one-quarter respectively. ${ }^{3}$ In analyzing the structure of the housing market, we shall concentrate on the decisions by builders to start construction on houses for sale or rental. We will not consider separately decision by individuals to build for their own use. We shall assume that individuals who build for their own use have the same impact on the market as builders and developers.

To facilitate our analysis of the housing market we shall make use of the flow

* This article is based on research supported by National Science Foundation Grant GS-1104.

† B.S. 1958, Millsaps College; B.S. 1959, Columbia University; M.B.A. I961, Indiana University; Ph.D. 1964, Tulane University. Associate Professor of Economics, Duke University. Co-author, [with E. T. Byrne] Linear Programming (1963); [with J. L. Balintfy, D. S. Burdick, \& K. Chu] Computer Simulation Techniques (I966); Editor, The Impact of the Computer on Society (1967). Contributor to journals in the fields of economics, management science, and computer science.

${ }^{1}$ Maisel, A Theory of Fluctuations in Residential Construction Starts, 53 Arr. Econ. REv. 359, 367 (I963).

${ }^{2}$ W. J. Frazer \& W. P. Yohe, Money and Banking 404 (1966).

${ }^{3}$ Maisel, Nonbusiness Construction, in The Brookings QuArTerly Econometric Model of this United StaTes I85 (1965). 
FIGURE I

Flow Chart of Construction in The Housing Market

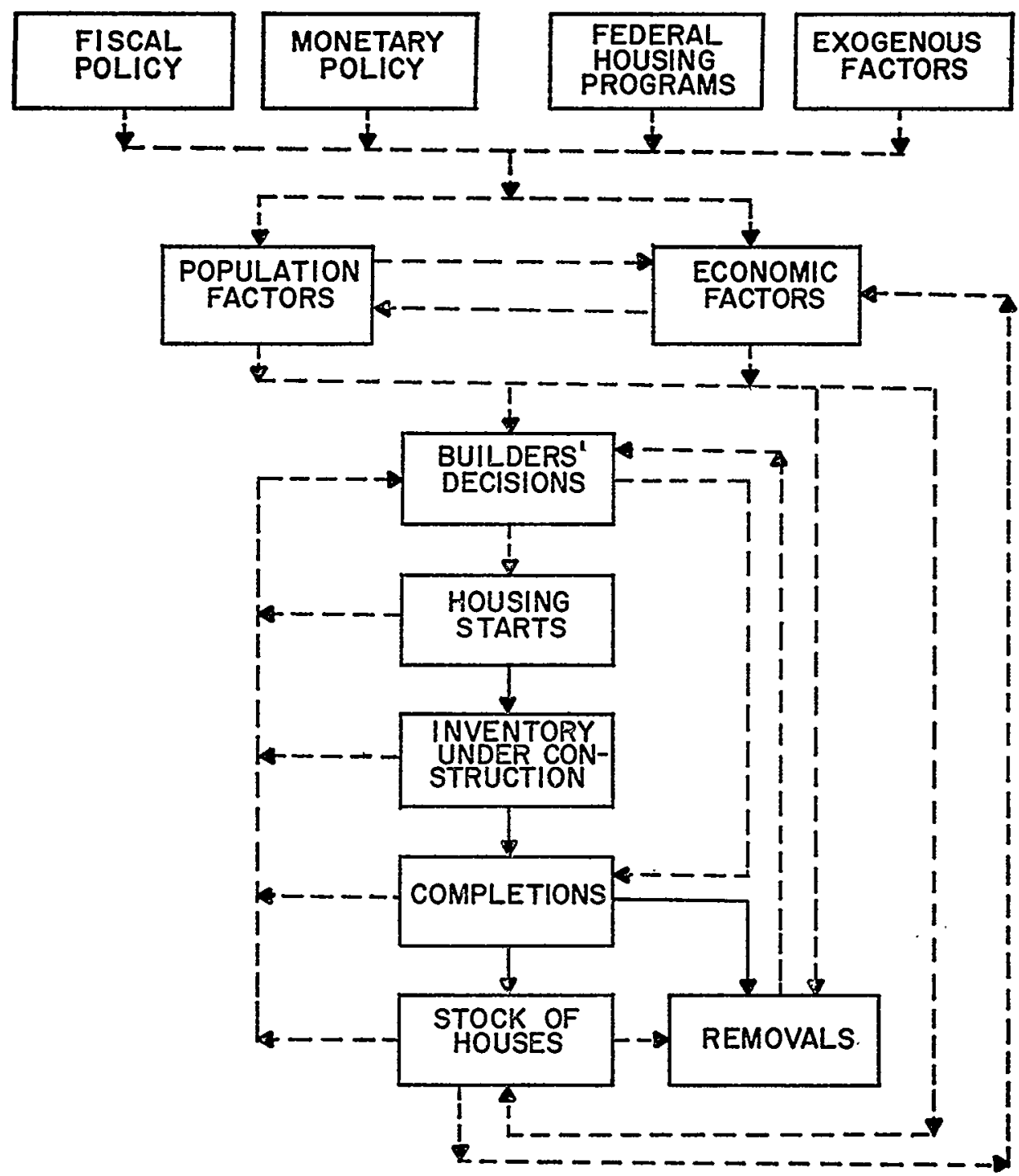

chart in figure I. The broken lines in figure I denote informational flows and the solid lines denote construction flows. Central to our flow chart of the housing market is the builder. He must continuously make two different types of decisions: (I) how many private housing units should be constructed and (2) what should be the size, quality, and value of each housing unit?

At any given point in time the stock of private dwellings $H_{\Delta V L}$ is equal to the 
Total Housing Stock in the United States on April r, rg6o

\begin{tabular}{|c|c|}
\hline 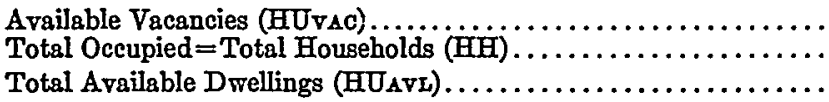 & $\begin{array}{r}1,975,000 \\
53,021,000 \\
54,966,000\end{array}$ \\
\hline
\end{tabular}

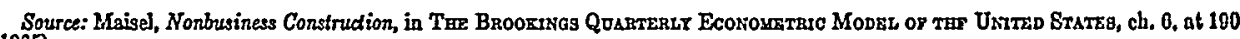
(1965).

number of households or occupied houses $\mathrm{HH}$ plus the number of houses which are vacant and available for occupancy $\mathrm{HU}_{\mathrm{VAO}}{ }^{4}$ That is,

$$
\mathrm{HU}_{\Delta \nabla \mathrm{L}}=\mathrm{HH}+\mathrm{HU}_{\mathrm{VAO}}
$$

For example, the total housing stock in the United States on April $x$, Ig60, is given in table $x$. Changes in the stock of houses occur when new houses are completed and when old houses are removed. Mathematically, the change in the stock of private housing may be described by the following identity,

$$
\triangle \mathrm{HU}_{\triangle \mathrm{VL}}=\mathrm{HU}_{\mathrm{FIN}}-\mathrm{HU}_{\mathrm{REM}}
$$

where $\triangle H U_{A V L}$ denotes a change in the housing stock, $H U_{\text {FIN }}$ denotes housing units completed, and $H_{\text {REM }}$ denotes net removals of housing units. From equation (I) it follows that $\triangle H U_{\Delta V L}$ may also be expressed as

$$
\Delta \mathrm{HU}_{\Delta \mathrm{VL}}=\Delta \mathrm{HH}+\Delta \mathrm{HU}_{\mathrm{VAO}}
$$

The number of completions during time period $T$ depends on the number of housing starts $\mathrm{HU}_{\text {STS }}$ in time periods $\mathrm{T}-\mathrm{I}, \mathrm{T}-2$, etc. Therefore, completions are identically equal to net household formation plus the change in vacancies and net removals,

$$
\mathrm{HU}_{\mathrm{FIN}}=\Delta \mathrm{HH}+\triangle \mathrm{HU}_{\mathrm{VAO}}+\mathrm{HU}_{\mathrm{REM}}
$$

Our principal concern in this article is with the process by which builders decide to increase, decrease, or hold constant the number of housing starts. The level of housing starts in any period is by definition equal to the sum of four variables,

$$
\mathrm{HU}_{\mathrm{STS}}=\Delta \mathrm{HH}+\mathrm{HU}_{\mathrm{REST}}+\Delta \mathrm{HU}_{\mathrm{VAO}}+\Delta \mathrm{HU}_{\mathrm{UO}}
$$

where $\triangle \mathrm{HU}_{\text {Uo }}$ is the change in the stock of housing units under construction. Table 2 shows the disposition of private housing starts between April I, 1950 and March 3r, Ig60.

Suppose that the housing market is in equilibrium at the beginning of planning period T. Builders start exactly enough houses to maintain a constant stock of housing units under construction. Completions are exactly equal to increases in the demand for housing (household formation plus removals),

$$
\mathrm{HU}_{\mathrm{FIN}}=\triangle \mathrm{HH}+\mathrm{HU}_{\mathrm{RESS}}
$$

In attempting to decide how many houses to construct during planning period

\footnotetext{
4Throughout this article we use notation developed by Sherman J. Maisel.
} 
TABLE 2

Disposition of Total Estimated Starts of Private Housing Untrs in the United States APRIL I, I950 To MARCH 3I, I960

\begin{tabular}{|c|c|}
\hline 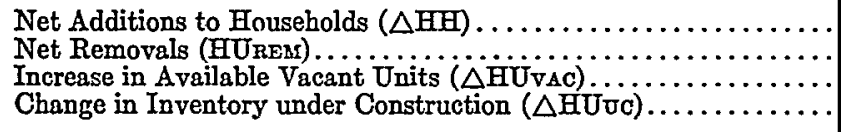 & $\begin{array}{r}9,645,000 \\
2,833,000 \\
1,245,000 \\
-37,000\end{array}$ \\
\hline Total Private Housing Starts (HUSTs).. & $13,686,000$ \\
\hline
\end{tabular}

Source: Maisel, A Theory of Fluctuations in Residential Construction Starts, 53 sar. EcoN. REv. 359, 361 (1963).

$T$, builders estimate the change in the actual number of new dwelling units coming into the market during planning period $\mathrm{T}$. That is, builders make conjectures about the magnitude of changes in the stock of houses as a result of completions during period $T$. The number of completions in period $T$ depends upon $(r)$ the number of starts in preceding periods, (2) the amount of resources committed by the builders to the completion process in period $T$, and (3) exogenous factors such as weather, strikes, and so on, which are beyond the control of builders. Builders also make conjectures about the change in the demand for housing $\left(\triangle H H+H U_{\text {REM }}\right)$ during planning period $T$. If builders conjecture that the increase in aggregate demand for housing during the planning period is likely to exceed the number of completions during that period, then conjectured profits will be relatively high and builders will increase the number of housing starts and increase the rate at which houses under construction are completed. On the other hand, if builders conjecture that completions will outrun the rate at which housing demand increases, vacancies will build up, conjectured profits will decline, and builders will cut back on housing starts and slow down completions. Builders are continuously making new conjectures about the housing market in the light of additional information which becomes available to them. Housing starts and completions are in turn continuously adjusted to reflect these changes in the builders' forecasts about the future.

What are some of the factors that cause builders to adjust the number of housing starts and the rate at which they employ resources to complete houses? Grebler and Maisel have developed a partial list of factors which affect builders' decisions about housing starts: ${ }^{5}$

I. Changes in population
a. Increase in population
b. Changes in the age-sex composition
c. Changes in the number, type, and size of households
d. Internal migration and immigration

\footnotetext{
${ }^{5}$ Grebler \& Maisel, Determinants of Residential Construction, in Commission on MoNey and CRedir, IMpacts of Monetary PoLicy 476-77 (Ig63).
} 
2. Changes in income and employment

a. Total disposable personal income: past, current, expected

b. Income distribution

c. Employment and unemployment

3. Consumer asset holdings and their distribution, especially liquid assets and equities in existing houses

4. Changes in the prices of housing

a. The price elasticity of housing relative to other prices

b. The shape of the construction supply and cost curves

5. Relationship between occupancy costs and prices of dwellings

a. Credit availability and the cost of credit

b. Real estate taxes and operating expenses

c. Depreciation

d. Imputed costs of equity funds

6. Consumer tastes and preferences

7. Net replacement demand for dwelling units demolished or otherwise removed from the inventory less net conversions and mergers of existing units.

8. Conditions in the existing housing supply

a. Utilization of the housing inventory

(I) Vacancies

(2) Intensity of occupancy

b. Prices and rents for existing dwelling units

c. Quality, location

9. Reaction to changes in demand

a. Builders' organization and profit expectations

b. Investors' organization and profit expectations

c. Market structure and market information

We have condensed these nine factors into three general categories in figure I: population factors, economic factors, and housing market factors. Each of these three factors is simultaneously determined by four variables: governmental fiscal policies, governmental monetary policies, federal housing programs, and exogenous variables such as weather, individual tastes, wars, and strikes, to mention only a few. In the remainder of this article we shall give particular attention to the impact of fiscal and monetary policies on the housing market.

\section{II}

Behavior of the Housing Market in the ig6os

Housing production as measured by housing starts "has earned the dubious distinction of ranking among the most cyclically volatile industries." ${ }^{\text {" }}$ During the

${ }^{\circ}$ Maisel, supre note $I$, at 359 . 
postwar years prior to Ig6o housing starts tended to rise sharply during recessions and during the early stages of recovery periods, reaching a peak about six months after the low point in general business activity. Throughout the remaining period of expanded business activity housing starts would continue to decline, thus providing a constraint on other expansive forces at work in the economy.

\section{Thousand}

\section{Private Nonfarm Housing Starts}

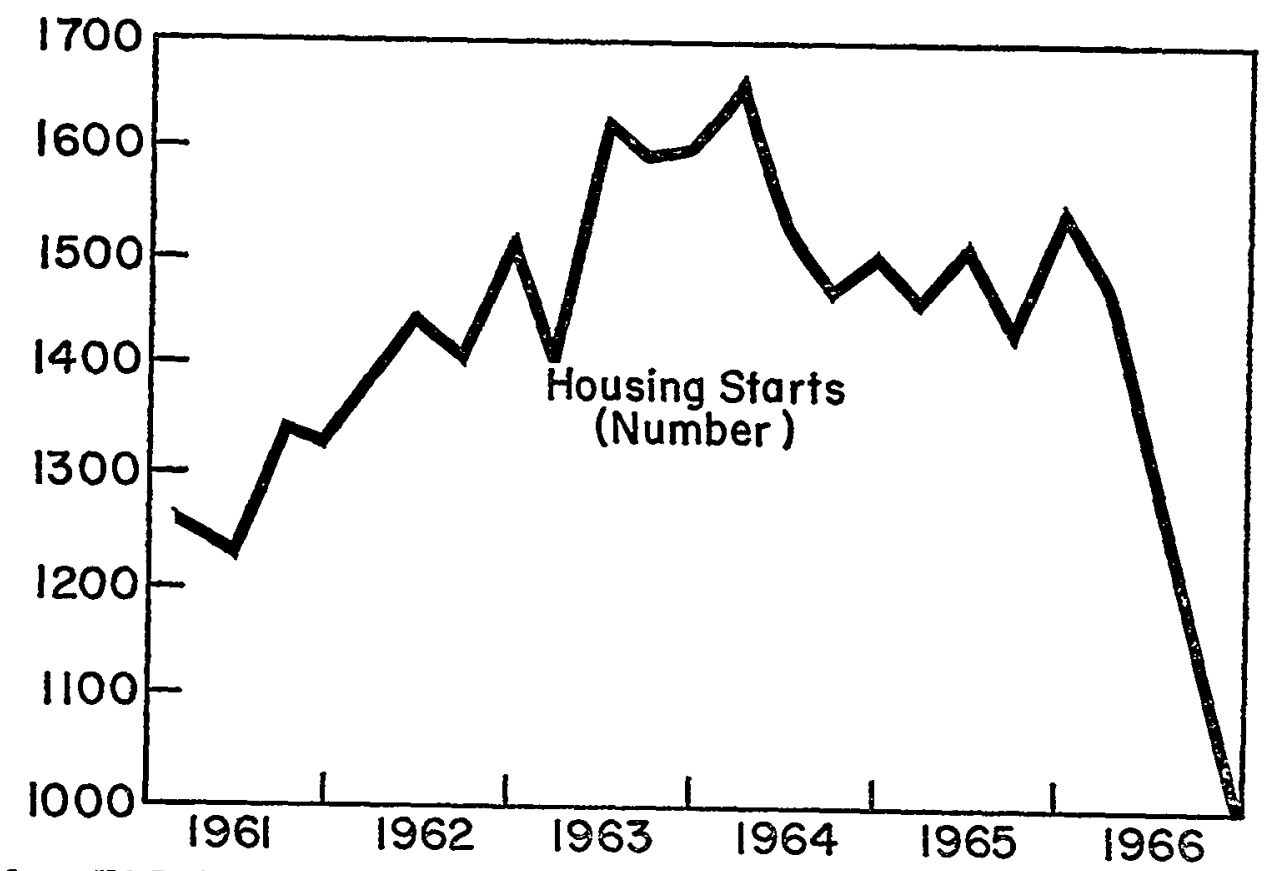

SOutce: U.S. DEP'T OF COMMARRCE.

During the Ig6os the U.S. economy has been characterized by a period of record expansion which began in early Ig6r and continued through the end of 1966 . Housing starts during this period have behaved in a manner which differs significantly from the pattern established in the earlier postwar years. (See figure 2.) There was no obvious upturn in housing starts prior to the beginning of the recovery period in Ig6r. The subsequent upswing in housing starts was quite mild, lasting only three years and reaching a peak in 1964 . Although the economy as a whole was continuing to expand in late 1966 , housing starts dropped to an annual rate of 1.0 million units in the fourth quarter of $x g 66$.

What caused the disappearance of the vitality which housing starts had displayed in the 1950 s? 
In previous cycles, housing had frequently moved contra-cyclically, rising in recession years because of low interest rates and abundant credit and then being choked off in recovery as rising demand for credit raised rates and shut off the flow of funds. While interest rates remained stable and funds were readily available, housing nevertheless responded only sluggishly and peaked out in early $1964 .^{7}$

Alhough no precise reason can be given for the relatively sluggish performance of the housing market in the Ig6os, a partial explanation may be a decline in the underlying demand for housing in the Ig60s.

With the tremendous blacklog of demand having been worked off in the I950's, housing activity in the early I960's did not surge forward as money became easy. In contrast to earlier experience, monetary policy in this latest expansion remained easy for a long time, and this probably contributed to the prolonged rise in housing activity, despite weaker underlying demand. The latter factor finally outweighed the stimulus of easy money and housing starts began drifting down from an annual rate of about $\mathrm{x} .6$ million units in early 1964 to about $x .5$ million units in early 1966 . Since that time a sharp rise in mortgage yields and reduced availability of mortgage credit have contributed to a precipitous drop. ${ }^{8}$

With the boom in apartment construction in the $1960 \mathrm{~s}$, the composition of residential construction has also changed considerably. In I960, multi-family housing starts represented twenty-one per cent of total housing starts. In $196_{3}$, they represented thirty-seven per cent of total housing starts.

\section{III}

\section{Impact of Fiscal Policy on the Housing Market}

The line of causality which links governmental fiscal policy with housing starts is far more complex than is implied by the flow chart in figure $x$. Changes in governmental fiscal policy affect aggregate demand (GNP) both directly and indirectly through a series of complex multiplier and feedback mechanisms. Changes in GNP may, in turn, affect disposable personal income, income distribution, employment, price levels, and so forth. Housing starts are sensitive in varying degrees to each of these economic parameters.

In general, two different types of fiscal policy instruments are available to the federal government-revenue policies and expenditure policies. Revenue policies or tax policies are those policies which determine: ( $x$ ) personal income tax rates, (2) corporate profit tax rates, (3) indirect business (excise) tax rates, and (4) contributions to social insurance (social security and Medicare). Conventional wisdom (macroeconomic theory) postulates that for given federal expenditure patterns, an increase (decrease) in tax rates will lead to a decrease (increase) in GNP. A decrease (increase) in GNP will indirectly affect housing starts by inducing changes in the intermediate economic variables (disposable income, employment, prices, and so on)

\footnotetext{
${ }^{7}$ Federai Reserve Bank of Richmond Ann. Rep. 8 (ig66).

${ }^{8}$ Id. at 26 .
} 
listed above. These economic factors may also affect certain demographic variables which tend to influence housing starts.

Alternatively, governmental policy makers may also affect GNP by increasing or decreasing governmental expenditures in the form of $(I)$ transfer payments or (2) purchases of goods and services. Transfer payments include payments to individuals in the form of social security benefits, Medicare benefits, unemployment compensation, and so on. For given tax rates, an increase (decrease) in government spending will usually lead to an increase (decrease) in GNP. As mentioned before, a change in GNP may trigger a change in housing starts.

Although there is general agreement among economists that governmental fiscal policy has substantially influenced the U.S. economy during the expansion period of the Ig6os, it is difficult to say to what extent fiscal policy affected the housing market. During the I96I-Ig66 expansion three types of governmental expenditures grew rapidly: expenditures for defense, expenditures for social security and older welfare programs, and expenditures for new welfare programs. On the revenue side, two innovations appeared during the 196os. First, two important measures were introduced specifically to reduce business taxes. These included liberalized depreciation allowances and a seven per cent investment tax credit. Second, there was a major reduction in personal and corporate income taxes in 1964 at a time when business was expanding and the budget was still showing a sizable deficit. Deficits in the federal cash budget were registered in every quarter but two during this period and usually ranged well over \$I billion. The expansionary effect of these deficits was especially important as is evidenced by the fact that GNP increased by nearly fifty per cent during this period. However, in late 1965 and early Ig66, as the economy began to approach full employment, these deficits generated strong inflationary pressures.

On the basis of this brief sketch of some of the major developments in governmental fiscal policy in the $\mathrm{x} g 60 \mathrm{~s}$ and on the basis of a cursory glance at the time path of housing starts during this period (figure 2), one can conclude that the relationship between fiscal policy and the housing market is somewhat less than straightforward. While the U.S. economy was responding vigorously to expansionary fiscal policies, the housing market demonstrated, at best, a "mixed" performance. It is virtually impossible to say anything meaningful about the relationship between fiscal policy and the housing market without resorting to sophisticated econometric models. In the following section we shall describe the results of several simulation experiments with alternative fiscal and monetary policies in which an econometric model was used to evaluate the impact of these policies on the housing market.

IV

Impact of Monetary Policy on the Housing Market

In grossly simplified terms, the purpose of monetary policies administered by the Federal Reserve Board is to influence the supply of money in the U.S. economy. 
Policies which tend to increase the supply of money available in the economy will lead to reductions in interest rates. Lower interest rates stimulate consumption and investment. Increased consumption and investment mean higher aggregate demand as well as increased personal income and employment. In terms of the housing market, lower interest rates imply lower credit costs; and, in theory, lower credit costs should stimulate the demand for housing.

In assessing the probable effects of interest rate changes on consumers' demand for credit for housing expenditures, however, it is important to recognize a purely numerical phenomenon. Aside from net income tax advantages associated with various amounts of interest payments, the mere fact that the typical mortgagor makes constant monthly payments on a very long-term mortgage means (I) that small changes in contractual interest rates have relatively little effect on the monthly payment (2) that, in turn, this latter change itself is likely to have only a small direct effect on consumers' demand for credit. ${ }^{9}$

As was the case with fiscal policies, the line of causality and functional relationships between monetary policy changes and the behavior of the housing market are extremely complex. Hypotheses concerning the nature of these relationships require extensive testing and verification before one can attach operational significance to them.

Three major policy instruments are available to the Federal Reserve: $(x)$ the open market purchase and sale of U.S. Government securities, (2) changes in the reserve requirements of member banks, and (3) changes in the discount rate, i.e., the interest rate charged to member banks by the Federal Reserve. The terms "tight money" and "easy money" are sometimes used to differentiate among alternative monetary policies. A "tight money" policy is one which tends to restrict the supply of money by (I) the sale of government securities, (2) raising reserve requirements, and (3) increasing the discount rate. "Easy money" policies are characterized by ( $\mathrm{I}$ ) the purchase of government securities, (2) decreased reserve requirements, and (3) lower discount rates.

Needless to say, one should proceed with extreme caution in advocating a particular monetary policy to achieve a specific goal in terms of interest rates, price levels, personal income, or employment. The pioneering work of Frank De Leeuw ${ }^{\mathbf{1 0}}$ and others at the Federal Reserve Board represents an initial attempt to quantify the effects of monetary policy on U.S. financial markets. De Leeuw's model has also been used as a sector of The Brookings Quarterly Econometric Model of the United States thus providing a linkage between monetary policy and the behavior of the entire U.S. economy. Unfortunately, it is impossible to adequately describe these two models and spell out their relationship to the housing market within the constraints imposed on the length of this article.

\footnotetext{
${ }^{\circ}$ W. J. Frazer \& W. P. Yohe, supra note 2, at 406.

${ }^{10} \mathrm{De}$ Leeuw, $A$ Model of Financial Behavior, in The Brookings Quarterly Econometric Model of THE UNITED STATES 465-530 (I965).
} 
During the expansion period of the I 960 , monetary policy can be briefly summarized as follows: Between 1960 and 1963 the Federal Reserve followed an active "easy money" policy. In early 1963 the Federal Reserve began moving toward a policy of "restrained ease" which continued through Ig64. In late Ig64 the economy began showing signs of overheating. Beginning in 1965 the Federal Reserve moved further in the direction of "tight money." By I966 a "tight money" policy was being pursued vigorously.

Turning to the relationship between monetary policy and housing starts, we observe in figure 2 that during the period of "easy money," when interests rates were relatively low and credit was readily available, housing starts increased in number. However, when the Federal Reserve turned to a "tight money" policy, housing starts reached a peak and turned downward at a rapid rate. By the spring of rg66 there was a severe squeeze on the market for mortgage funds. The situation had become so acute for potential home builders or buyers and for the construction industry that the Federal Reserve put into effect several special measures designed to channel additional funds into the mortage market.

Perhaps the most promising attempt to date to evaluate the impact of monetary (and fiscal) policies on the housing market is the paper by Gary Fromm entitled "An Evaluation of Monetary Policy Instruments."11 Fromm uses The Brookings Quarterly Econometric Model of the United States and computer simulation techniques to evaluate four different monetary actions and two fiscal policy alternatives. ${ }^{12}$ The version of the Brookings Model used by Fromm consists of 176 simultaneous equations. The financial sector of the model numbers over thirty equations. Of particular interest to us is the fourteen-equation nonbusiness construction model developed by Sherman J. Maisel which is contained within the complete Brookings Model. Maisel's model relates nonfarm residential construction to a number of variables including: ( $\mathrm{I}$ ) a housing cost index; (2) housing starts in periods $\mathrm{T}$, T-r, and T-2; (3) total available housing; (4) the implicit price deflator for nonfarm construction; and (5) the implicit price deflator for GNP. The model also includes an equation which expresses housing starts as a function of: ( $\mathrm{r}$ ) changes in the number of households; (2) net removals of housing; (3) vacant available housing in period T-r; (4) the rent component of the consumer price index in period T-I; (5) average market yield of three-month U.S. Treasury bills; and (6) housing starts in periods T-I and T-3.

In Fromm's simulation experiments the discount rate, average reserve ratios required against demand and time deposits, and the unborrowed reserves of member banks (controlled by Federal Reserve open market operations) were treated as mone-

\footnotetext{
${ }^{11}$ Presented at the annual meeting of the Econometric Society, San' Francisco, December 29, I966.

${ }^{13}$ Computer simulation is defined as a numerical technique for conducting experiments on a digital computer with a mathematical model describing an economic system. See T. H. NAYLoR, J. L. BaLINTrF, D. S. Burdick \& K. Chu, Computer Simuzation Techniques (ig66).
} 
tary policy instruments. Given the structural coefficients of the equations of the Brookings Model and certain other exogenous variables (i.e., population and governmental expenditures), then the model determines the values of the endogenous variables which describe the system. Six separate simulations were run. The simulations included four different monetary policy changes and two different fiscal policy changes. The monetary policy changes were: (I) a cut in the discount rate, (2) a reduction in the time deposits reserve requirements, (3) a reduction in the demand deposits reserve requirements, and (4) an increase in unborrowed reserves (open market operations). The fiscal policy changes were: (I) an increase in government durables purchases and (2) a reduction in personal federal income tax rates. In each simulation, all other parameters and exogenous variables remained unchanged. A control simulation was also run. All of the simulations were for the mid-1960 through 1962 recession period (seven quarters). The control simulation represents an approximation to the actual behavior of the economy during the $1960-62$ period. The simulations provide some indication of events that might have taken place had the above monetary and fiscal policy changes been instituted at the end of the second-quarter of 1960 .

The two fiscal policy changes had relatively little impact on nonfarm residential construction. Of the four monetary policy changes, the reduction in the demand deposits reserve requirements and the increase in unborrowed reserves stimulated nonfarm residential construction by the greatest amount over the seven-quarter period. The cut in the discount rate had the greatest sustaining effect on the housing market. For all of the policies, with the exception of the discount rate reduction, the impact on business plant and equipment investment is greater than the impact on nonfarm residential construction. This implies that the responsiveness (elasticities) of business investment to changes in interest rates and income are greater than the responsiveness of nonfarm residential construction to changes in interest rates and income.

\section{$\mathrm{V}$}

The Impact of Federal Housing Programs on the Housing Market

In addition to fiscal and monetary policies, the housing market is also affected by a number of governmental housing programs. These programs include:

I. Veterans Administration

2. Department of Housing and Urban Development

a. Federal National Mortgage Association

b. Public Housing Administration

c. Federal Housing Administration

3. Home Loan Bank Board 
The principal aim of the Veterans Administration (VA) and the Federal Housing Administration (FHA) is to make available credit for home purchases by insuring the lenders of funds against loss. The Veterans Administration guarantees at no cost a portion of the value of loans to eligible veterans, thus eliminating or greatly reducing the usual cash down payment for the purchase of a home. The federal housing program is an insurance program under which approved lenders are insured for the full amount of their mortgage loans in return for a premium paid by the home owner. "One of the effects of the VA- and FHA-underwritten mortgages, however, has been to cause housing expenditures to vary, at times, counter to the short cycle of income, output, and employment."13 The objective of the Federal National Mortgage Association ("Fannie Mae") is to increase the liquidity of government-insured mortgages (VA and FHA) by providing a secondary market facility to widen the market for government-insured mortgages. The Federal Home Loan Bank Board, a part of the Home Loan Banking System, provides credit to home financing institutions. The Public Housing Administration has focused its attention on the development of low-rent housing facilities for lower-income families.

What effects have these programs had on the housing market?

Considerable literature exists on the effects of Federal housing programs on the composition of residential construction and on short term fluctuations. Most of it is of the verbal-qualitative type. With one exception, the statistical-econometric models at best concern themselves with the effects of changes in credit conditions generally, without attempting to examine and quantify the component sources of such changes. The long-run impact on the level of construction has had relatively little attention. Yet, whether the extensive housing aids offered by the Federal Government have helped raise the level of new construction or accelerate the growth of the housing sector would seem to be a strategic question. ${ }^{\mathbf{1 4}}$

Although the average yield on FHA- and VA-home mortgage loans would appear to be seemingly obvious credit variables in evaluating the impact of federal housing programs on the housing market, because of intricacies in the mortgage market (e.g., discounting) they are, in fact, poor measures of the cost of credit. In concluding his econometric study of the housing market, Maisel stated:

Because credit is an important government policy variable, significant changes in past relationships may occur which must be considered in analysis and forecasting. Clearly, if the Federal Reserve succeeds in breaking past relationships between the Treasury bill rate and the availability and cost of credit, ... [housing starts] will be affected. Even more important may be the changing policies of the Federal National Mortgage Association. In this study [Maisel's study], FNMA intervention in the credit market appeared significant on theoretical grounds, and nearly so on a statistical basis. However, since FNMA action was closely related in time to interest rate movements, it did little to increase our sta-

\footnotetext{
${ }^{13}$ W. J. Frazer \& W. P. Yohe, stupra note 2, at 408 .

${ }^{1 *}$ Grebler \& Maisel, supra note 5, at 584 .
} 
tistical explanation of past movements. Even though this collinearity did result in insignificant [regression] coefficients ... [in an equation relating FNMA policy to housing starts], it seems logical to assign direct governmental intervention of this type a good deal of weight, even if only subjectively. ${ }^{15}$

\section{VI}

\section{SUMMARY}

We have outlined a number of possible relationships between fiscal and monetary policy, as well as federal housing programs, and the housing market. Although a large number of empirical studies of the housing market have been conducted, none of these studies has as its principal aim the delineation of relationships between fiscal and monetary policy (and governmental housing programs) and the housing market. The major conclusion of this study is, therefore, that there is considerable need for an econometric model of the housing market which includes as instrumental variables (I) fiscal policy instruments (2) monetary policy instruments, and (3) federal housing program instruments. Until such a model is constructed, generalizations about the relationship between these policy instruments and the behavior of the housing market can at best be termed "speculative."

\footnotetext{
${ }^{15}$ Maisel, supra note $I$, at 378 .
} 